\title{
Assessing Heavy Metal Pollution in Surface Sediments of China's Shaying River
}

\author{
Kaisheng Zhou* \\ Geographical Science School of Nanjing Normal University, Nanjing, China \\ Center of Environment Science Experiment, Bengbu University, Bengbu, China
}

Received: 24 June 2018

Accepted: 8 September 2018

\begin{abstract}
To comprehend the contamination levels of heavy metals in surface sediments of Shaying River (Anhui Section, China), samples of sediments were collected using grab samplers in 14 sampling sites in the river. Chromium $(\mathrm{Cr})$, cadmium $(\mathrm{Cd})$, copper $(\mathrm{Cu})$, and lead $(\mathrm{Pb})$ in sediments were monitored via flame atomic absorption spectroscopy, and arsenic (As) via atomic fluorescence spectroscopy. The geo-accumulation index $\left(I_{\text {geo }}\right)$, pollution load index $(P L I)$, and potential ecological risk index $(R I)$ were applied to evaluate the sediment pollution of the five heavy metals. The results indicate that the mean concentration levels (range) of $\mathrm{Cr}, \mathrm{Cd}, \mathrm{Cu}, \mathrm{Pb}$, and $\mathrm{As}$ in sediments were 58.38 (29.89-116.66), 5.41 (3.14-10.93), 38.51 (23.77-60.83), 35.10 (19.28-82.21), and 0.44 (0.13-1.46) $\mathrm{mg} / \mathrm{kg}$, respectively. The mean $I_{\text {geo }}$ values of $\mathrm{Cr}, \mathrm{Cd}, \mathrm{Cu}, \mathrm{Pb}$, and As were $-0.69,5.41,0.36,-0.13$, and -4.84, respectively. The average potential ecological coefficients $\left(E_{r}^{i}\right)$ of $\mathrm{Cr}, \mathrm{Cd}, \mathrm{Cu}, \mathrm{Pb}$, and As were 1.95, 324.70, 6.42, 7.02, and 0.29 , respectively. The $R I$ values of the five heavy metals ranged from 197.65 to 687.24 , and the mean was 340.38. Among the studied heavy metals, Cd was the highest contaminating element, whereas As was the lowest. Especially $\mathrm{Cd}$ was the main contributor to $R I$ in all the sampling sites. Moreover, $\mathrm{Cr}$, $\mathrm{Cd}, \mathrm{Pb}$, and As might have similar sources of contamination based on the Pearson correlation matrix of analysis.
\end{abstract}

Keywords: heavy metals; heavy metal pollution; potential ecological risk; Shaying River; surface sediments

\section{Introduction}

Heavy metal pollution is one of the most serious threats to aquatic environmental quality and human health due to the toxicity [1], persistence [2], nondegradability [2], and bioaccumulation [3] of heavy metals in surroundings. Heavy metals have been known

*e-mail: zks606@sina.com to have direct toxic effects when released into the aquatic environment, and sediments function as a sink for these pollutants [4]. Heavy metal contaminants from urban, industrial, and agricultural sources that are poured into rivers will eventually combine with sediments via physical precipitation, chemical absorption, and biological absorption, and then deposited into surface sediments [5-7]. Heavy metals can accumulate and migrate in surface sediments because of cumulative effects and long-term interactions. Surface sediments serve as the main reservoir of heavy metals in a river 
and are frequently used to reflect heavy metal pollution in rivers [8]. Sediments act as carriers and possible sources of contamination because heavy metals are not perennially adsorbed onto them and may be released back to the water with changes in environmental conditions [9], i.e., heavy metals deposited into sediments will be released, reenter the water body, and cause secondary pollution in the river [10]. The accumulation of heavy metals in surface sediments negatively affects the ecological environmental safety of a catchment area and threatens animals and plants [11]. The heavy metals chromium (Cr), cadmium $(\mathrm{Cd})$, copper $(\mathrm{Cu})$, lead $(\mathrm{Pb})$, and arsenic (As) exhibit considerable environmental toxicity; $\mathrm{Cd}, \mathrm{Pb}$, and $\mathrm{As}$ are also environmental hormones [12]. Humans and other organisms in nature may be directly or indirectly affected by exposure to these contaminants [4]. The concentrations of heavy metals in surface sediments and their potential ecological hazards differ according to geological conditions and human activities in various catchment areas. The contents of heavy metals vary considerably in surface sediments from disparate sections of the same river. At present, the environmental ecological hazard caused by heavy metal pollution remains a controversial topic [13-14].

Shaying River is the largest tributary of the Huai River, with a total length of approximately $620 \mathrm{~km}$ and a catchment area of approximately $40000 \mathrm{~km}^{2}$. The river originates from Funiu Mountains in Henan Province, China. Shaying River flows through the cities of Zhoukou and Fuyang plus nearly 40 counties and towns before finally flowing into the Huai River in Yingshang
County, Anhui Province, China. The climate in its catchment area belongs to a warm temperate semi-humid monsoon climate with an average annual precipitation of $750 \mathrm{~mm}$. With the rapid growth of the population and the development of industry and agriculture, Shaying River is becoming one of the most polluted tributaries of the Huai River due to water quality deterioration [15-16]. The pollution load of Shaying River accounts for approximately $1 / 3$ of the total pollution load of the Huai River basin [17]. For example, the large-scale pollution accidents that occurred in the Huai River in 1994, 2001, 2002, and 2004 were related to sewage discharge from the Shaying River [16-17]. Therefore, the contamination of heavy metals in the surface sediments of the Shaying (Anhui Section, China) should be studied and evaluated. The current study aims to provide a scientific basis for controlling aquatic environmental pollution in the Shaying.

\section{Materials and Methods}

\section{Collection of Sediment Samples}

Surface sediments (approximately the top $10 \mathrm{~cm}$ ) were collected using grab samplers in December 2011. Fig. 1 shows the locations of the sampling sites from Jieshou to the estuary of the Shaying River. A total of 14 sample sites were selected, and 3 to 5 samples were collected from each sampling site. For each sample, plastic spoons were used to remove the surface layer $(0-2 \mathrm{~cm})$, and the remaining soil was used as a test

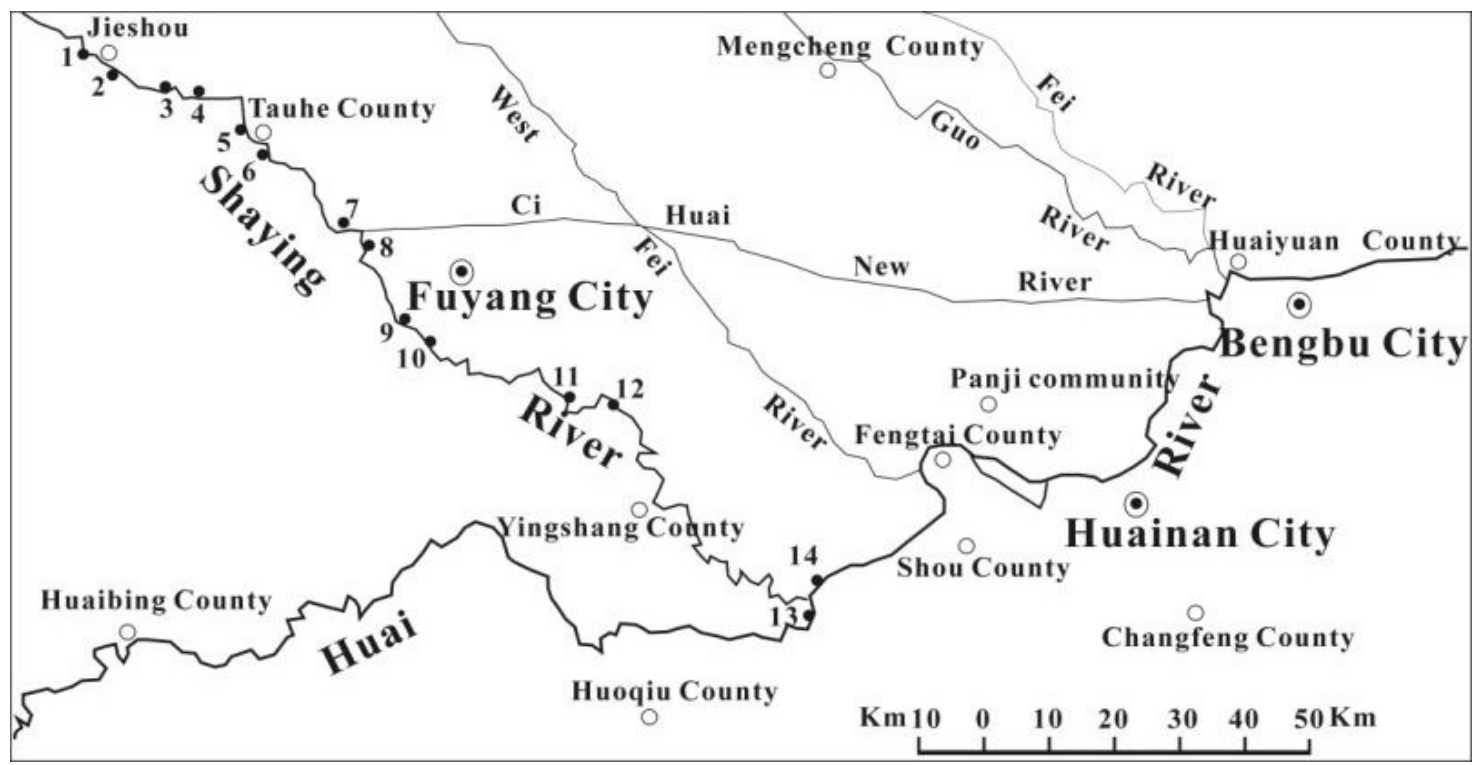

Fig. 1. Map of sampling sites

Notes: 1 - Bridge of Shaying River in Jieshou 1 (JS1); 2 - Bridge of Shaying River in Jieshou 2 (JS2); 3 - Tianying 1 (TY1); 4 - Tianying 2 (TY2); 5 - Old bridge of Shaying River in Taihe County 1 (TH1); 6 - Old bridge of Shaying River in Taihe County 2 (TH2); 7 - Estuary of Ci Huai New River 1 (CH1); 8 - Estuary of Ci Huai New River 2 (CH2); 9 - Fourth bridge of Shaying River 1 (YH1); 10 - Fourth bridge of Shaying River 2 (YH2); 11 - Funan County 1 (FN1); 12 - Funan County 2 (FN2); 13 - Estuary of Shaying River 1 (YK1); 14 - Estuary of Shaying River 2 (YK2) 
sample and placed in a self-sealing plastic bag. After mixing, sealing, and numbering, the samples were brought back to the laboratory and stored in a refrigerator at $0-4^{\circ} \mathrm{C}$.

\section{Analysis of Samples}

The sediment samples were air-dried at room temperature for approximately 2 weeks, ground to powder using an agate mortar and pestle, and then passed through a 100-mesh nylon screen. Undersized materials were gathered and kept in sample containers. A precise weight of each sample $(0.200 \mathrm{~g})$ obtained using an electronic balance (Mettler AE200, Switzerland) was used to prepare the solution for the digestion reaction. A mixture of concentrated $\mathrm{HCl}(10 \mathrm{~mL}), \mathrm{HNO}_{3}$ $(5 \mathrm{~mL}), \mathrm{HClO}_{4}(5 \mathrm{~mL})$, and $\mathrm{HF}(5 \mathrm{~mL})$ was used for the digestion reaction. Heavy metal $(\mathrm{Cr}, \mathrm{Cd}, \mathrm{Cu}$, and $\mathrm{Pb}$ ) concentrations were determined using a graphite furnace atomic absorption spectrophotometer (TAS-990, Beijing General Instrument Co., Ltd., China). Another precise weight of each sample (0.200 g), obtained using an electronic balance (Mettler AE200, Switzerland), was placed in a conical flask with a volume of $150 \mathrm{~mL}$. A mixture of $\mathrm{H}_{2} \mathrm{SO}_{4}$ solution $(7 \mathrm{~mL}$, the volume ratio of $\mathrm{H}_{2} \mathrm{SO}_{4}$ to water is $\left.1: 1\right)$, concentrated $\mathrm{HNO}_{3}(10 \mathrm{~mL})$, and $\mathrm{HClO}_{4}(2 \mathrm{~mL})$ was used for the digestion reaction to monitor the heavy metal As. The concentration of As in each sample was determined using a double-channel atomic fluorescence photometer (AFS-920, Beijing Beifen-Ruli Analytical Instrument Group Co., Ltd., China).

\section{Assessment Method for Sediment Pollution}

\section{Geo-Accumulation Index $\left(I_{\text {ged }}\right)$}

$I_{\text {geo }}$ is an effective method for assessing the pollution level of heavy metals in sediments. It is defined by the following equation [18]:

$$
I_{\text {geo }}=\log _{2}\left[C_{n} /\left(1.5 \times B_{n}\right)\right]
$$

...where $C_{n}$ is the concentration of the heavy metal n, and stands for the geo-chemical background level (mg/ $\mathrm{kg}$ ). Factor 1.5 is used for possible lithological variations in the background value based on a previously reported shale value [18]. Müller [19] established seven classes of $I_{\text {geo }}$ values for each heavy metal: $I_{\text {geo }} \leq 0$, unpolluted; $0<I_{\text {geo }}<1$, unpolluted to moderately polluted; $1<I_{\text {geo }}<2$, moderately polluted; $2<I_{\text {geo }}<3$, moderately to heavily polluted; $3<I_{\text {oeo }}<4$, heavily polluted; $4<C<5$, heavily to extremely polluted; and $I_{\text {geo }}>5$, extremely polluted.

\section{Pollution Load Index (PLI)}

The contamination factor $(C F)$ was calculated using equation [20]:
Table 1. Reference values $\left(C_{n}^{i}\right)$ and toxic coefficient $\left(T_{r}^{i}\right)$ of heavy metals.

\begin{tabular}{|c|c|c|c|c|c|}
\hline Heavy metal elements & $\mathrm{Cr}$ & $\mathrm{Cd}$ & $\mathrm{Cu}$ & $\mathrm{Pb}$ & $\mathrm{As}$ \\
\hline$C_{n}^{i} /(\mathrm{mg} / \mathrm{kg})$ & 60 & 0.5 & 30 & 25 & 15 \\
\hline$T_{r}^{i}$ & 2 & 30 & 5 & 5 & 10 \\
\hline
\end{tabular}

$$
C_{f}^{i}=C_{m}^{i} / C_{n}^{i}
$$

...where $C_{m}{ }^{i}$ is the concentration of an element in the analyzed sample, and $C_{n}{ }^{i}$ corresponds to the background value [20]. In the present study, the soil background values of Anhui Province [21] were selected as references. The contamination factor $\left(C_{f}^{i}\right)$ accounts for the pollution of a single element. The following terminology can be used in this method to describe $C F$ : $C_{f}^{i}<1$, low pollution; $1 \leq C_{f}^{i}<3$, moderate pollution; $3 \leq C_{f}^{i}<6$, considerable pollution; and $C_{f}^{i} \geq 6$, very high pollution [20, 22].

$P L I$ is calculated using the equation [23]:

$$
P L I=\left(C F_{1} \times C F_{2} \times C F_{3} \times \ldots \times C F_{n}\right)^{1 / n}
$$

...which provides a simple and comparative means to evaluate the polymetallic pollution of sediments. A PLI value of 0 is perfect; a value of 1 denotes baseline levels of contaminants; values less than 1 indicate no pollution; and values above 1 signify the progressive deterioration of polymetallic pollution [24-26].

\section{Potential Ecological Risk Index (RI)}

RI, which was developed by Hakanson [20], was used to assess the ecological hazard of each investigated metal in the aquatic environment. This index is calculated using the equation:

$$
E_{r}^{i}=T_{r}^{i} \times C_{f}^{i}
$$

...where $C_{f}^{i}$ and $T_{r}^{i}$ refer to the contamination factor and toxic-response factor of a given substance, respectively. The following terminology can be used to describe the risk factor: $E_{r}{ }^{i}<40$, low risk; $40 \leq E_{r}{ }^{i}<80$, moderate risk; $80 \leq E_{r}^{i}<160$, considerable risk; $160 \leq E_{r}^{i}<320$, high risk; and $E_{r}^{i} \geq 320$, very high risk. $R$ is defined as the sum of the risk factors, i.e.,

$$
R I=\sum_{i=1}^{n} E_{r}^{i}=\sum_{i=1}^{n} T_{r}^{i} \times C_{f}^{i}=\sum_{i=1}^{n} T_{r}^{i} \times C_{m}^{i} / C_{n}^{i}
$$

The $R I$ value may be used with the following terminology: $R I<150$, low ecological risk; $150 \leq R I<300$, moderate risk; $300 \leq R I<600$, considerable risk; and $R I \geq 600$, very high risk [24-25]. The reference values 
Table 2. Heavy metal concentrations $(\mathrm{Cr}, \mathrm{Cd}, \mathrm{Cu}, \mathrm{Pb}$, and $\mathrm{As})$ in Shaying River (Anhui Section, China) sediments (mg/kg).

\begin{tabular}{|c|c|c|c|c|c|}
\hline Samples & $\mathrm{Cr}$ & $\mathrm{Cd}$ & $\mathrm{Cu}$ & $\mathrm{Pb}$ & $\mathrm{As}$ \\
\hline JS1 & 60.48 & 5.06 & 31.63 & 34.42 & 0.21 \\
\hline JS2 & 47.07 & 5.82 & 32.15 & 27.73 & 0.30 \\
\hline TY1 & 52.20 & 6.10 & 29.83 & 39.78 & 0.14 \\
\hline TY2 & 29.89 & 5.06 & 24.40 & 22.42 & 0.13 \\
\hline TH1 & 69.27 & 4.76 & 33.56 & 35.70 & 0.91 \\
\hline TH2 & 52.36 & 4.90 & 29.40 & 36.89 & 0.17 \\
\hline CH1 & 81.49 & 4.92 & 54.80 & 64.63 & 0.77 \\
\hline CH2 & 116.66 & 10.93 & 60.83 & 82.21 & 1.46 \\
\hline YH1 & 47.94 & 4.40 & 52.55 & 34.75 & 0.60 \\
\hline YH2 & 45.51 & 4.57 & 29.14 & 21.19 & 0.40 \\
\hline FN1 & 89.17 & 6.05 & 31.49 & 36.02 & 0.28 \\
\hline FN2 & 41.47 & 3.64 & 51.23 & 24.56 & 0.23 \\
\hline YK1 & 39.91 & 3.14 & 23.77 & 19.28 & 0.16 \\
\hline YK2 & 41.23 & 5.15 & 35.22 & 19.33 & 0.33 \\
\hline Mean & 58.19 & 5.32 & 37.14 & 35.64 & 0.44 \\
\hline [21] & 62.6 & 0.0837 & 19.3 & 26.0 & 8.4 \\
\hline
\end{tabular}

$\left(C_{n}^{i}\right)$ [26] and toxic coefficient $\left(T_{r}^{i}\right)$ [24] of heavy metals in this study are presented in Table 1.

\section{Data Analysis}

In this study, the statistical analysis software SPSS Statistics 16.0 (SPSS Inc., Chicago, USA) was used for the correlation matrix analysis of heavy metals in surface sediments. Microsoft Excel (version 2007) was used for the processing and statistical analysis of test data.

\section{Results and Discussion}

\section{Heavy Metal Contents in Sediments}

The obtained heavy metal contents in the surface sediments of Shaying River (Anhui Section, China) are provided in Table 2. The elemental contents were 29.89-116.66 for $\mathrm{Cr}$ (mean: 58.19), 3.14-10.93 for $\mathrm{Cd}$ (mean: 5.32), 23.77-60.83 for $\mathrm{Cu}$ (mean: 37.14), 19.28-82.21 for $\mathrm{Pb}$ (mean: 35.64), and 0.13-1.46 for As (mean: 0.44$) \mathrm{mg} / \mathrm{kg}$, respectively. The heavy metal contents in surface sediments in this study ranked in decreasing order are as follows: $\mathrm{Cr}>\mathrm{Cu}>\mathrm{Pb}>\mathrm{Cd}>\mathrm{As}$.

With the exception of $\mathrm{Cr}$ and $\mathrm{As}$, the mean contents of the other studied heavy metals in all the sampling sites exceeded their corresponding background values [21]. If the 14 sampling sites were classified into 7 sampling areas, the sums of the mean content of the 5 heavy metals in each sampling area that were deposited into the surface sediments of Shaying River ranged from high to low were as follows: $\mathrm{CH}(239.3 \mathrm{mg} / \mathrm{kg})>\mathrm{FN}$ $(142.2 \mathrm{mg} / \mathrm{kg})>\mathrm{TH}(133.9 \mathrm{mg} / \mathrm{kg})>\mathrm{JS}(122.5 \mathrm{mg} / \mathrm{kg})>\mathrm{YH}$ $(120.6 \mathrm{mg} / \mathrm{kg})>\mathrm{TY}(105.0 \mathrm{mg} / \mathrm{kg})>\mathrm{YK}(93.9 \mathrm{mg} / \mathrm{kg})$.

Compared with other published studies on rivers in China, the average concentration value of $\mathrm{Cd}$ in the current research was higher than those of the Huai [27], Yellow [28], Yangtze [26], Pearl [29], Hai [30], Liao [31], Songhua [32], and Jialu [33] rivers. By contrast, the mean concentration value of As was lower than those of the Huai [27], Yellow [28], Yangtze [26], Pearl [29], Hai [34], Liao [31], Songhua [32], and Jialu [33] rivers. The mean concentration value of $\mathrm{Cr}$ was lower than those of the Yellow [28], Yangtze [26], Pearl [29], Hai [34], Songhua [32], and Jialu [33] rivers, but higher than those of the Huai [27] and Liao [31] rivers. The mean concentration value of $\mathrm{Cu}$ was lower than those of the Yellow [28], Yangtze [26], Pearl [29], Hai [30], and Jialu [33] rivers, but higher than those of the Huai [27], Liao [31], and Songhua [32] rivers. The average concentration value of $\mathrm{Pb}$ was higher than those of the Huai [27],

Table 3. Heavy metal concentrations in the riverbed sediments of Shaying River (Anhui Section, China) and other rivers in China $(\mathrm{mg} / \mathrm{kg})$ based on published studies.

\begin{tabular}{|c|c|c|c|c|c|c|}
\hline Location & $\mathrm{Cr}$ & $\mathrm{Cd}$ & $\mathrm{Cu}$ & $\mathrm{Pb}$ & As & References \\
\hline Shaying River & 58.19 & 5.32 & 37.14 & 35.64 & 0.44 & this study \\
\hline Huai River & 56.10 & 0.17 & 22.20 & 20.40 & NA & [27] \\
\hline Yellow River & 62.40 & 0.085 & 40.70 & 15.2 & 2.46 & [28] \\
\hline Yangtze River & 73.11 & 0.44 & 44.50 & 34.55 & 25.33 & [26] \\
\hline Pearl River & 93.10 & 1.72 & 348.00 & 102.60 & NA & [29] \\
\hline Hai River & 81.90 & 0.36 & 53.30 & 20.00 & 10.16 & {$[30,34]$} \\
\hline Liao River & 36.45 & 1.42 & 18.36 & 11.47 & 10.22 & {$[31]$} \\
\hline Songhua River & 121.40 & 0.27 & 13.33 & 18.80 & 10.13 & {$[32]$} \\
\hline Jialu River & 60.80 & 2.93 & 39.22 & 29.35 & 6.31 & {$[33]$} \\
\hline
\end{tabular}


Table 4. $I_{g e o}, C F s$, and $P L I$ of the studied metals in Shaying River sediments (Anhui Section, China).

\begin{tabular}{|c|c|c|c|c|c|c|c|c|c|c|c|}
\hline \multirow{2}{*}{ Sample } & \multicolumn{2}{|c|}{$\mathrm{Cr}$} & \multicolumn{2}{|c|}{$\mathrm{Cd}$} & \multicolumn{2}{|c|}{$\mathrm{Cu}$} & \multicolumn{2}{|c|}{$\mathrm{Pb}$} & \multicolumn{2}{|c|}{ As } & \multirow{2}{*}{ PLI } \\
\hline & $I_{g e o}$ & $C F$ & $I_{g e o}$ & $C F$ & $I_{g e o}$ & $C F$ & $I_{g e o}$ & $C F$ & $I_{g e o}$ & $C F$ & \\
\hline JS1 & -0.63 & 1.01 & 5.33 & 10.12 & 0.13 & 1.05 & -0.18 & 1.38 & -5.91 & 0.01 & 0.73 \\
\hline JS2 & -1.00 & 0.78 & 5.53 & 11.64 & 0.15 & 1.07 & -0.49 & 1.11 & -5.39 & 0.02 & 0.74 \\
\hline TY1 & -0.85 & 0.87 & 5.60 & 12.20 & 0.04 & 0.99 & 0.03 & 1.59 & -6.49 & 0.01 & 0.69 \\
\hline TY2 & -1.65 & 0.50 & 5.33 & 10.11 & -0.25 & 0.81 & -0.80 & 0.90 & -6.60 & 0.01 & 0.50 \\
\hline TH1 & -0.44 & 1.15 & 5.24 & 9.52 & 0.21 & 1.12 & -0.13 & 1.43 & -3.79 & 0.06 & 1.01 \\
\hline TH2 & -0.84 & 0.87 & 5.29 & 9.80 & 0.02 & 0.98 & -0.08 & 1.48 & -6.21 & 0.01 & 0.68 \\
\hline $\mathrm{CH} 1$ & -0.20 & 1.36 & 5.29 & 9.84 & 0.92 & 1.83 & 0.73 & 2.59 & --4.03 & 0.05 & 1.27 \\
\hline $\mathrm{CH} 2$ & 0.31 & 1.94 & 6.44 & 21.86 & 1.07 & 2.03 & 1.08 & 3.29 & -3.11 & 0.10 & 1.94 \\
\hline YH1 & -0.97 & 0.80 & 5.13 & 8.80 & 0.86 & 1.75 & -0.17 & 1.39 & -4.39 & 0.04 & 0.93 \\
\hline YH2 & -1.04 & 0.76 & 5.19 & 9.14 & 0.01 & 0.97 & -0.88 & 0.85 & -4.98 & 0.03 & 0.69 \\
\hline FN1 & -0.07 & 1.49 & 5.59 & 12.10 & 0.12 & 1.05 & -0.11 & 1.44 & -5.49 & 0.02 & 0.87 \\
\hline FN2 & -1.18 & 0.69 & 4.86 & 7.28 & 0.82 & 1.71 & -0.67 & 0.98 & -5.78 & 0.02 & 0.66 \\
\hline YK1 & -1.23 & 0.67 & 4.64 & 6.28 & -0.28 & 0.79 & -1.02 & 0.77 & -6.30 & 0.01 & 0.49 \\
\hline YK2 & -1.19 & 0.69 & 5.36 & 10.30 & 0.28 & 1.17 & -1.01 & 0.77 & -5.25 & 0.02 & 0.68 \\
\hline Mean & -0.69 & 0.97 & 5.41 & 10.64 & 0.36 & 1.24 & -0.13 & 1.43 & -4.84 & 0.03 & 0.88 \\
\hline
\end{tabular}

Yellow [28], Yangtze [26], Hai [30], Liao [31], Songhua [32], and Jialu [33] rivers, but lower than that of the Pearl [29] River (Table 3).

\section{Assessment of Sediment Contamination}

The results of $I_{g e o}, C F s$, and $P L I$ in this study are presented in Table 4. Heavy metals were categorized according to various classes based on $I_{\text {geo }}$ values related to the degree of pollution. The $I_{\text {geo }}$ values of the elements ranged from -1.65 to 0.31 for $\mathrm{Cr}$ (mean: -0.69 ), -6.60 to 0.33 for As (mean: -4.84 ), and -1.02 to 1.08 for $\mathrm{Pb}$ (mean: -0.13 ), which indicate unpolluted; -0.28 to 1.07 for $\mathrm{Cu}$ (mean: 0.36), which denote unpolluted to polluted; and 4.64 to 6.44 for $\mathrm{Cd}$ (mean: 5.41 ), which signify heavily to extremely polluted. The elements exhibited the following order: $\mathrm{Cd}>\mathrm{Cu}>\mathrm{Pb}>\mathrm{Cr}>\mathrm{As}$.

All five heavy metals accumulated to different extents, except for As. Nearly $64.3 \%$ of the sites presented $\mathrm{Cu}$, and $\mathrm{Pb}$ accumulation, whereas $100 \%$ of the sites exhibited $\mathrm{Cd}$ accumulation. The $C F$ values were 6.28-21.86 for $\mathrm{Cd}$ (mean: 10.64), which indicate very high contamination; 0.77-3.29 for $\mathrm{Pb}$ (mean: 1.43) and 0.79-2.03 for $\mathrm{Cu}$ (mean: 1.24), which denote moderate contamination; and 0.50-1.94 for Cr (mean: 0.97) and 0.01-0.1 for As (mean: 0.03), which suggest low contamination. The degree of contamination followed the order of $\mathrm{Cd}>\mathrm{Pb}>\mathrm{Cu}>\mathrm{Cr}>\mathrm{As}$. From the preceding analysis, a conclusion can be drawn that $\mathrm{Cd}, \mathrm{Pb}, \mathrm{Cu}$, and $\mathrm{Cr}$ are the main metals that can have detrimental impacts on the riverine ecosystem.
The $P L I$ values ranged from 0.49 to 1.94 , with a mean of 0.88 . Among all the sampling sites, 3 of 14 values were $>1$, thereby suggesting that $21.4 \%$ of the sites were a progressive deterioration of polymetallic pollution. The most substantial contamination occurred in $\mathrm{CH} 2$, $\mathrm{CH} 1$, and TH1, as shown in the spatial distribution of the $P L I$ values.

\section{Risk Associated with Heavy Metals}

Potential ecological risk assessment appropriately combines ecological effects and toxicology. It has been widely used to assess the risks posed by heavy metals to an ecosystem and to humans. The potential hazard to aquatic organisms related to the measured metal concentrations was assessed using potential ecological risks. The results of $E_{r}{ }^{i}$ and $R I$ are presented in Table 5. The $E_{r}{ }^{i}$ values were 188.4-655.8 for Cd (mean: 319.3 ), which indicated high to very high ecological risk; 3.9-16.4 for $\mathrm{Pb}$ (mean: 7.1), 4.0-10.1 for $\mathrm{Cu}$ (mean: 6.2), 1.0-3.9 for $\mathrm{Cr}$ (mean: 1.9), and 0.1-1.0 for As (mean: 0.3), which implied low potential ecological risk. Therefore, the degree of potential ecological risk of the five elements exhibited the following order based on their mean values: $\mathrm{Cd}>\mathrm{Pb}>\mathrm{Cu}>\mathrm{Cr}>\mathrm{As}$.

The $R I$ values of the five heavy metals ranged from 197.65 to 687.24 , which denoted moderate to very high ecological risk. Among them, 1 of $14 R I$ values in $\mathrm{CH} 2$ was $>600$, which indicated very high ecological risk; 9 of $14 R I$ values were $300 \leq R I<600$, which denoted considerable ecological risk; and 4 of $14 R I$ values were $150 \leq R I<300$, which implied moderate ecological 
Table 5. $E_{r}^{i}, R I$, and the hazards of heavy metals in Shaying River riverbed sediments (Anhui Section, China).

\begin{tabular}{|c|c|c|c|c|c|c|}
\hline \multirow{2}{*}{ Samples } & \multicolumn{5}{|c|}{$E_{r}^{i}$} & \multirow{2}{*}{$R$} \\
\hline & $\mathrm{Cr}$ & $\mathrm{Cd}$ & $\mathrm{Cu}$ & $\mathrm{Pb}$ & As & \\
\hline JS1 & 2.02 & 303.60 & 5.27 & 6.88 & 0.14 & 317.91 \\
\hline JS2 & 1.57 & 349.20 & 5.36 & 5.55 & 0.20 & 361.87 \\
\hline TY1 & 1.74 & 366.00 & 4.97 & 7.96 & 0.09 & 380.76 \\
\hline TY2 & 1.00 & 303.36 & 4.07 & 4.48 & 0.09 & 312.99 \\
\hline TH1 & 2.31 & 285.60 & 5.59 & 7.14 & 0.61 & 301.25 \\
\hline TH2 & 1.75 & 294.00 & 4.90 & 7.38 & 0.11 & 308.14 \\
\hline $\mathrm{CH} 1$ & 2.72 & 295.20 & 9.13 & 12.93 & 0.51 & 320.49 \\
\hline $\mathrm{CH} 2$ & 3.89 & 655.80 & 10.14 & 16.44 & 0.97 & 687.24 \\
\hline YH1 & 1.60 & 264.00 & 8.76 & 6.95 & 0.40 & 281.71 \\
\hline YH2 & 1.52 & 274.20 & 4.86 & 4.24 & 0.27 & 285.08 \\
\hline FN1 & 2.97 & 363.00 & 5.25 & 7.20 & 0.19 & 378.61 \\
\hline FN2 & 1.38 & 218.40 & 8.54 & 4.91 & 0.15 & 233.39 \\
\hline YK1 & 1.33 & 188.40 & 3.96 & 3.86 & 0.11 & 197.65 \\
\hline YK2 & 1.37 & 309.00 & 5.87 & 3.87 & 0.22 & 320.33 \\
\hline
\end{tabular}

risk. The $R I$ values of each site decreased in the following order: $\mathrm{CH} 2>\mathrm{TY} 1>\mathrm{FN} 1>\mathrm{JS} 2>\mathrm{CH} 1>\mathrm{YK} 2>\mathrm{JS} 1$ $>\mathrm{TY} 2>\mathrm{TH} 2>\mathrm{TH} 1>\mathrm{YH} 2>\mathrm{YH} 1>\mathrm{FN} 2>\mathrm{YK} 1$. Cd was the main contributor to $R I$ in all the sampling sites. The $R I$ values in all the sites were $>150$ and were all above the threshold (i.e., 150).

Natural and anthropogenic sources contribute to the levels of $\mathrm{Cd}$ found in sediments from sources, such as mine/smelter wastes, phosphate fertilizers, sewage sludge, and municipal waste landfills [35]. The high contents and ecological risk of $\mathrm{Cd}$ in the sediments of Shaying River (Anhui, China) are closely related to the discharge of industrial wastewater (such as mining, smelting, electroplating, and dyeing wastewater) and of farmland wastewater [36]. Heavy metal pollution in Shaying River sediments mainly comes from its mainstream and tributaries in the middle and upper reaches of the Shaying River [36]. Ruyang County, which belongs to the Shaying River system, is located in the upper and middle reaches of the Shaying River, where mineral resources are abundant, especially the metal mines, whose mining and smelting generate a large amount of Cd pollution. The Jialu River is one of the tributaries of the Shaying, of which the stream segment with typical black smelly water flows through Zhengzhou City. The new materials and the opto-mechatronics industry are the pillar industries of the high-tech zone of Zhengzhou City, Henan Province, China. Substantial amounts of raw or industrial wastewater were discharged into the Jialu River without treatment, leading to Cd pollution. The Beiru River is another tributary of the Shaying flowing through Ye County, which is a famous industrial county of Pingdingshan
City, Henan Province, China. The shipping, mining, and chemical industries of Ye County are advanced, thereby easily causing serious Cd pollution [36]. The $\mathrm{Cd}$ from the upstream with running water sinks into the bottom sediments along with the floating particles in the water. Moreover, the middle and lower reaches of the Shaying flow through regions, including Jieshou, Fuyang City, Taihe County, and Yingshang County, where the population density is high and the mining, chemical, and agricultural industries are advanced, thereby resulting in high content and ecological risk of $\mathrm{Cd}$ in the surface sediments of the Shaying. $\mathrm{Cd}$ and its compounds are highly toxic, which can enter the body through food, water, or dust inhalation [37]. Longterm $\mathrm{Cd}$ exposure can have chronic and acute effects on human health, and $\mathrm{Cd}$ poisoning can cause lung, kidney, and bone damage, and itai-itai disease [37]. As an important carcinogen, $\mathrm{Cd}$ and its compounds have

Table 6. Pearson correlation coefficient matrix of heavy metals in Shaying River surface sediments (Anhui Section, China).

\begin{tabular}{|c|c|c|c|c|c|}
\hline & $\mathrm{Cr}$ & $\mathrm{Cd}$ & $\mathrm{Cu}$ & $\mathrm{Pb}$ & $\mathrm{As}$ \\
\hline $\mathrm{Cr}$ & 1 & & & & \\
\hline $\mathrm{Cd}$ & $0.764 * *$ & 1 & & & \\
\hline $\mathrm{Cu}$ & $0.552^{*}$ & 0.422 & 1 & & \\
\hline $\mathrm{Pb}$ & $0.878^{* *}$ & $0.765^{* *}$ & $0.702 * *$ & 1 & \\
\hline $\mathrm{As}$ & $0.772 * *$ & $0.671^{* *}$ & $0.715^{* *}$ & $0.793^{* *}$ & 1 \\
\hline
\end{tabular}

Notes: ** Correlation is significant at the 0.01 level (2-tailed)

* Correlation is significant at the 0.05 level (2-tailed) 
been classified as Group I by the International Agency for Research on Cancer [35]. Chen et al. [38] reported that the contents of heavy metals and cancer-causing health risk in the environment of the Shaying River Basin were significantly higher in high-incidence areas of typical cancer than in other areas, and the contents of $\mathrm{Cd}$ were more than twice that of other areas. Therefore, further attention should be given to $\mathrm{Cd}$ because it poses a high risk of heavy metal contamination to the Shaying sediments (Anhui Section, China).

\section{Source Apportionment of Heavy Metal Pollutants}

The Pearson correlation matrix of analysis is useful for determining the source and pathway of contaminants in riverbed sediments [39]. The corresponding analytical results are presented in Table 6. All the confidence levels among $\mathrm{Cr}, \mathrm{Cd}, \mathrm{Pb}$, and As reached 95\%, thereby indicating that these heavy metals might have similar sources of contamination [32, 40]. $\mathrm{Cu}$ presented significant correlations with $\mathrm{Cr}, \mathrm{Pb}$, and $\mathrm{As}$, with confidence levels of $99 \%, 99 \%$, and $95 \%$, respectively, thereby implying that the sources of $\mathrm{Cu}$ might be similar to those of $\mathrm{Cr}, \mathrm{Pb}$, and As. However, $\mathrm{Cu}$ demonstrated weak positive correlation with $\mathrm{Cd}$, which indicates that $\mathrm{Cu}$ may have other sources of contamination that differ from those of $\mathrm{Cd}$ [41].

\section{Conclusion}

From the preceding analysis, different levels of heavy metal contamination were identified in the surface sediments of Shaying River (Anhui Section, China). Among the studied metals, Cd was the highest contaminating element, whereas As was the lowest contaminating element. The ecological risk of $\mathrm{Cd}$ ranged from high to very high, whereas $\mathrm{Cu}, \mathrm{Pb}, \mathrm{Cr}$, and $\mathrm{As}$ posed low potential ecological risk. The comprehensive potential ecological risk of the five elements belonged to considerable ecological risk, and $\mathrm{Cd}$ was the main contributor to $R I$ in all the sampling sites. Moreover, $\mathrm{Cr}, \mathrm{Cd}, \mathrm{Pb}$, and As might have similar sources of contamination based on the Pearson correlation matrix of analysis.

\section{Acknowledgements}

This research was supported by the quality engineering project of Anhui Province, China (2015zy068); the talent program of Bengbu University ([2014]182); the project of research innovation for Jiangsu Province ordinary university graduate students in 2013 (CXLX13_370); the project of professional engineering teaching reform (environmental science) (2017GCHZY2); and the project of Anhui Province revitalization plan (2014zdjy137).

\section{Conflict of Interest}

The authors declare no conflict of interest.

\section{References}

1. LI B., YU S., LI G.L., LIU Y., YU G.B., DENG H., WU S.C., WONG M.H. Urbanization increased metal levels in lake surface sediment and catchment topsoil of waterscape parks. Sci. Total Environ. 432, 202, 2012.

2. CHEN H.Y., CHEN R.H., TENG Y.G., WU J. Contamination characteristics ecological risk and source identification of trace metals in sediments of the Le'an River (China). Ecotox. Environ. Safe. 125, 85, 2017.

3. KILUNGA P., SIVALUNGAM P., LAFFITE A., GRANDJEAN D., MULAJI C.K. Accumlation of toxic metals and organic micro-pollutants in sedi- ments from tropical urban rivers, Kinshasa, Democratic Republic of the Congo. Chemosphere. 179, 37, 2017.

4. ADEKOLA F.A., ELETTA O.A.A. A study of heavy metal pollution of Asa River, Ilorin. Nigeria; trace metal monitoring and geochemistry. Environ Monit Assess. 125, 157, 2007.

5. CHEN J., YUAN J., WU S., LIN B., YANG Z. Distribution of trace element contamination in sediments and riverine agricultural soils of the Zhongxin River, South China, and evaluation of local plants for biomonitoring. J. Environ. Monit. 14, 2663, 2012.

6. LI X., SHEN Z., WAI O.W., LI Y.S. Chemical forms of $\mathrm{Pb}, \mathrm{Zn}$ and $\mathrm{Cu}$ in the sediment profiles of the Pearl River Estuary. Mar. Pollut. Bull. 42 (3), 215, 2001.

7. SIN S.N., CHUA H., LO W., NG L.M. Assessment of heavy metal cations in sediments of Shing Mun River, Hong Kong. Environ. Int. 26 (5-6), 297, 2001.

8. SEGURA R., ARANCIBIA V., ZÚÑIGA M.C., PASTÉN P. Distribution of copper, zinc, lead and cadmium concentrations in stream sediments from the Mapocho River in Santiago, Chile. J. Geochem. Explor. 91 (1-3), 71, 2006.

9. JR H.M., HORSFALL M.N., SPIFF A.I. Speciation of heavy metals in inter - tidal sediments of the Okirika river system, Rivers State, Nigeria. B. Chem. Soc. Ethiopian. 13 (1), 1, 1999.

10. DONG A., ZHAI S., ZABEL M., YU Z., ZHANG H. Heavy metals in Changjiang estuarine and offshore ediments: responding to human activities. Acta Oceanol. Sinica. 31 (2), 88, 2012.

11. CHANG C.Y., YU H.Y., CHEN J.J., LI F.B., ZHANG H.H., LIU C.P. Accumulation of heavy metals in leaf vegetables from agricultural soils and associated potential health risks in the Pearl River Delta, South China. Environ. Monit. Assess. 186, 1547, 2014.

12. TERELAK H., STUCZYNSKI T., PIOTROWSKA M. Heavy metals in agricultural soils in Poland. Polish J. Soil Sci. 30 (2), 35, 1997.

13. LIN C., YU R., HU G., YANG Q., WANG X. Contamination and isotopic composition of $\mathrm{Pb}$ and $\mathrm{Sr}$ in offshore surface sedi- ments from Jiulong River, Southeast China. Environ. Pollut. 218, 644, 2016.

14. YANG Z., WANG Y., SHEN Z., NIU J., TANG Z. Distribution and speciation of heavy metals in sediments from the mainstream, tributaries, and lakes of the Yangtze River catchment of Wuhan, China. J. Hazard. Mater. 166 (2-3), 1186, 2009. 
15. ZHONG M., WAN Y., WAN A., HU J., AN S., LENG X. Pollution characteristics and ecological risk assessment of heavy metals in the sediments of Shaying River. Chinese J. Ecol. 35 (7), 1857, 2016 [In Chinese].

16. WANG Y., ZUO Q. Analysis of water quality change and its reasons in Henan Reach of Shayinghe River. J.Water Res. Water Eng. 23 (4), 47, 2012 [In Chinese].

17. HAO S., PENG W., WU W., XU J. Research on spatial distribution of non-point source pollution load in Shaying River Basin. Yangtze River. 45 (17), 6, 2014 [In Chinese].

18. MÜLlER G. Schwermetalle in den Sedimenten des Rheins-Veränderungen seit 1971. Umschau. 79 (24), 778, 1979.

19. MÜLLER G. Die Schwermetallbelastung der sedimente des Neckars und seiner Nebenflusse: eine Bestandsaufnahme. Chemiker-Zeitung. 105, 157, 1981.

20. HAKANSON L. An ecological risk index for aquatic pollution control. a sedimentological approach. Water Res. 14 (8), 975, 1980.

21. CHINA NATIONAL ENVIRONMENTAL MONITORING CENTRE. Background value of Chinese soil elements, 1st ed.; Publisher: Environmental science press, Beijing, China, 330, 1990 [In Chinese].

22. KADHUM S.A., ISHAK M.Y., ZULKIFLI S.Z. Evaluation and assessment of baseline metal contamination in surface sediments from the Bernam River, Malaysia. Environ. Sci. Pollut. Res. 23, 6312, 2016.

23. TOMLINSON D.L., WILSON J.G., HARRIS C.R., JEFFREY D.W. Problems in the assessment of heavymetal levels in estuaries and the formation of a pollution index. Helgoländer Meeresuntersuchungen. 33, 566, 1980.

24. AZHARI A.E., RHOUJJATI A., HACHIMI M.L.E. Assessment of heavy metals and arsenic contamination in the sediments of the Moulouya River and the Hassan II Dam downstream of the abandoned mine Zeïda (High Moulouya, Morocco). J. Afr. Earth Sci. 119, 279, 2016.

25. XU F., LIU Z., CAO Y., QIU L., FENG J., XU F., TIAN X. Assessment of heavy metal contamination in urban river sediments in the Jiaozhou Bay catchment, Qingdao, China. Catena. 150, 9, 2017.

26. YI Y., YANG Z., ZHANG S. Ecological risk assessment of heavy metals in sediment and human health risk assessment of heavy metals in fishes in the middle and lower reaches of the Yangtze River basin. Environ. Pollut. 159, 2575, 2011.

27. YAN J., HE Y., HUANG H. Characteristics of heavy metals and their evaluation in sediments from middle and lower reaches of the Huaihe River. J. China Univ. Min. Tech. 17 (3), 414, 2007.

28. YAN N., LIU W., XIE H., GAO L., HAN Y., WANG M., LI H. Distribution and assessment of heavy metals in the surface sediment of Yellow River, China. J. Environ. Sci. 39, 45, 2016.

29. NIU H., DENG W., WU Q., CHEN X. Potential toxic risk of heavy metals from sediment of the Pearl River in South China. J. Environ. Sci. 21, 1053, 2009.
30. TANG W., ZHAO Y., WANG C., SHAN B., CUI J. Heavy metal contamination of overlying waters and bed sediments of Haihe River in China. Ecotoxicol. Environ. Saf. 98, 317, 2013.

31. KE X., BAO Q., HUANG X., ZHANG H. Toxicity assessment of sediments from the Liaohe River protected area (China) under the influence of ammonia nitrogen, heavy metals and organic contaminants. Environ. Toxicol. Pharmacol. 59, 34, 2018.

32. LI N., TIAN Y., ZHANG J., ZUO W., ZHAN W., ZHANG J. Heavy metal contamination status and source apportionment in sediments of Songhua River Harbin region, Northeast China. Environ. Sci. Pollut. Res. 24, 3214, 2017.

33. FU J., ZHAO C., LUO Y., LIU C., KYZAS G.Z., LUO Y., ZHAO D., AN S., ZHU H. Heavy metals in surface sediments of the Jialu River, China: Their relations to environmental factors. J. Hazard. Mater. 270, 102, 2014.

34. WANG C., SHAN B., ZHANG H., ZHAO Y. Limitation of spatial distribution of ammonia-oxidizing microorganisms in the Haihe River, China, by heavy metals. J. Environ. Sci. 26, 502, 2014.

35. WASEEM A., ARSHAD J., IQBA F., SAJJAD A., MEHMOOD Z., MURTAZA G. Pollution Status of Pakistan: A Retrospective Review on Heavy Metal Contamination of Water, Soil, and Vegetables. Biomed Res. Int. 2014, 1, 2014

36. ZHONG M., WAN Y., WAN A., HU J., AN S., LENG X. Pollution characteristics and ecological risk assessment of heavy metals in the sediments of Shaying River. Chinese Journal of Ecology, 35 (7), 1857, 2016 [In Chinese].

37. CAMBRA K., MARTÍMEZ T., URZELAI A., ALONSO E. Risk analysis of a farm area near a lead- and cadmiumcontaminated industrial site. Soil Sediment Contam. 8 (5), 527, 1999.

38. CHEN Y., LI T., MA J., DONG W., RUAN X. Health risk assessment of heavy metal accumulation in soil and groundwater in a typical high cancer incidence area of Huai River basin. Acta Scientiae Circumstantiae, 36 (12), 4537, 2016 [In Chinese].

39. BARTOLI G., PAPA S., SAGNELlA E., FIORETTO A. Heavy metal content in sediments along the Calore river: Relationships with physicalechemical characteristics. J. Environ. Manage. 95, S9, 2012.

40. XIAO H., ZANG, S., GUAN Y., LIU S., GAO Y., SUN Q., XU H., LI M., WANG J., PEI X. Assessment of potential risks associated with heavy metal contamination in sediment in Aobaopao Lake, China, determined from sediment cores. Ecotoxicology. 23, 527, 2014.

41. MAANAN M., SADDIK M., MAANAN M., CHAIBI M., ASSOBHEI O., ZOURARAH B. Environmental and ecological risk assessment of heavy metals in sediments of Nador lagoon Morocco. Ecol. Indic. 48, 616, 2015. 